\title{
地利值と重力モデル \\ CONVENIENT POSITION-VALUE AND GRAVITY MODEL
}

大澤義明*1, 林 利 充*2

\section{Yoshiaki OHSAWA and Toshimitsu HAYASHI}

\begin{abstract}
The aim of this paper is to analyze the distribution of convenient position-values defined on a connected undirected graph. Such values are defined only by the connectiveity of the graph, but meet equilbrium condition on the graph. First, we prove the convenient position-value are distributed according to gravity model using a negative exponential distribution. Then, we exhibit the echo effect and characterize the distribution of convenient position-value on a monocentric city. Finally, we compare radial, external ring and radial-arc graphs routings in terms of convenient position-values.
\end{abstract}

Keywords: convenient position-value, radial-arc, graph, monocentric city, gravity model 地利值，放射環状網，グラフ，単一中心都市，重力モデル

\section{1 はじめに}

商業施設の選択行動などハフモデルは盛んに使われている ${ }^{1) 2)}$. この考え方は，商業施設から遠くなるにつれて利用する客は減少す るという前提に基づく。このような距離聥隇構造を理論的に説明し た研究として, ウイルソンの空間相互作用モデルが有名である3)4). エントロピーを最大化するとゾーン間の交流が距離の指数関数で 莪減するというものである。また，人口密度が都市機能の集積度が 高い都心からの距離の指数関数で低下することを実証した有名なク ラークの法則もある ${ }^{5)}$ ．地価計量モデルに関しても，都心から郊外 に向かって指数関数で遁減するという前提で数多く構築されてきた. 本研究では，グラフの隣接関係から求められ，各ノードで定義され

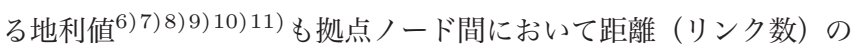
指数関数で減少することを証明する。つまり，個々のノードの魅力 度を取り入れない単純な構造を表現するグラフではあるが，そこか ら計算できる地利值が重力モデルに従って減衰することを理論的に 明らかにする。こうして，本研究は重力モデルを応用するための理 論的裏付けを別の角度から提供する。

地利值は，グラフの隣接行列の固有ベクトルの成分值である. 隣 接グラフの固有值は代数的性質とグラフの位相的性質との橋渡しと なり，多くの専門書も出版されている12)13)14)15)。また，このよう な固有值は，地域間境界を表現した隣接行列から算出される空間的
相関係数とも関連している ${ }^{16)}$. 地利值を解析的に表現できるグラ フは少ないが，最近の計算技術に関する進展や計算速度の向上によ り，固有值計算プログラムを用いて小規模であればどのようなグラ フに対しても地利值の数值は機械的に求められるようになった。し かし, 地利值の普遍的性質が導出されているとは言い難い. 多くの グラフで成立する結果が本質な知見であろう。特に, 地利值の関数 型を特定できれば，例えば回帰分析等によるデー夕計算といった他 の計量アプローチによりパラメータを推計することも可能となる.

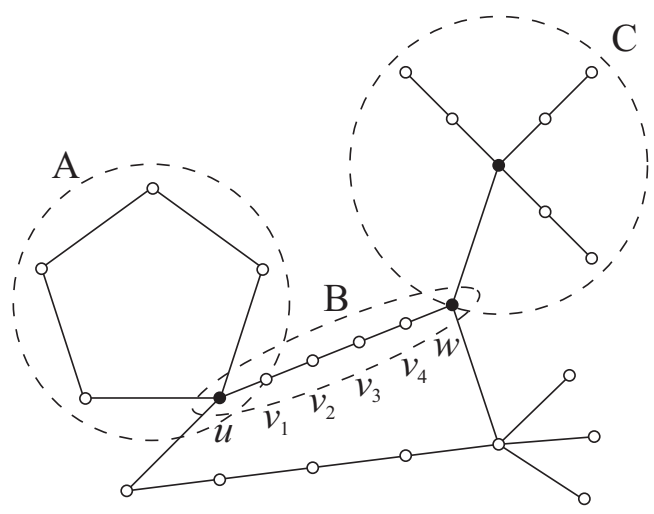

図 1 グラフと 3 種類の部分グラフ

\footnotetext{
*1 筑波大学 教授. 学博

*2 国際航業(侏) 修士(社会工学)

Prof., University of Tsukuba, Ph. D.

Kokusai Kogyo Co., Ltd., Master of Policy and Planning Sciences
} 
本研究の目的は, 地利值の分布が拠点ノード間リンク数に関する 指数関数型の重力モデルで表現できることを示すことにある．この 目的を以下の 2 つの状況において達成する.

第一に, 図 1 のように, 全体から部分グラフを切り出し, その部 分グラフ内の地利值を分析する。実際に対象とする地域は孤立して いるはずがなく，多くの地域と連携しているため，本来であれば大 規模なグラフに対して地利值を計算しなければならない.しかし， 例えば日本全体での計算量は膨大であり，実行することは現実的で ない. 都市計画や地域計画といった現実の空間を対象とする研究に おいて着目するのは，ネットワーク全体のある限られた地域内での 相対的関係であり, 切り出した部分グラフにおける地利值の相対量 を特徵付けるだけでもその意義は大きい. 本研究で切り出す部分は, 外部と接続するノード (図中の・) が 1 点もしくは 2 点である. 図 の点線で囲んだ環状部分（図中の $A$ ）や直線部分 (図中の $B$ ), さ らには同心円部分（図中の $C$ ）の 3 種類である。このような部分グ ラフにおける地利值の分布が，外部との接続点からのノード間リン ク数に関して指数関数で表示できることを示す.

第二に, 単一中心都市構造を想定し, 様々な放射環状グラフにお ける地利值の分布を特徵付ける。図 2 に, 地域の中心核となる拠 点ノード (中心) から伸びる放射路と地点間を結ぶ環状路が存在す る同心円地域構造を示す。チューネン圈を学ぶ地理学 ${ }^{17)}$, アロンゾ 土地利用モデルを軸とする都市経済学 ${ }^{18)}$, 道路網パターンを解析 する交通工学 19 20) などの分野においては標準的な設定である。ま た，多くの諸都市がこのような構造となっていることが指摘されて いる ${ }^{21)}$. 中心地には駅や空港等のターミナルがあり, 外界との出入 り口の役割も担っている。このような単一中心都市構造における地 利值の分布が, 中心地からのリンク数に関する指数関数で表現でき ることを示す。

商業施設立地では地点ごとの魅力に着目し，ノードごとに異なる 魅力を与えるが, 本研究ではどのノードも同一の魅力とし, ノード 間の距離も一定と単純化する。このような状況において, グラフ構 造から必然的に発生する地利值が，距離の指数関数に従って派減す ることを理論化する。

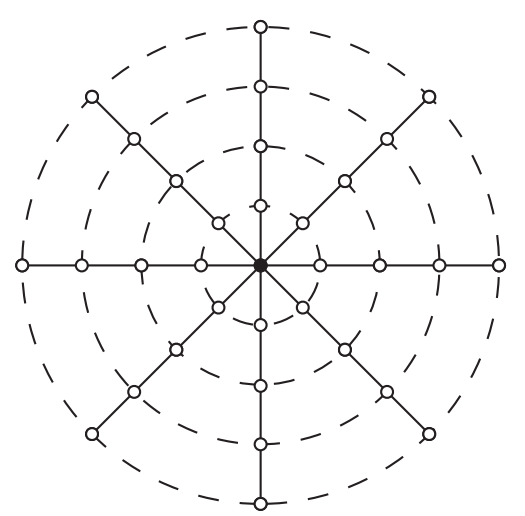

図 2 同心円地域
2 地利値

2.1 固有值 ・固有ベクトル

地域間の相互作用関係を表現する無向連結グラフを考える。 $V$ を そのノード集合， $E$ をそのリンク集合とし，実質的な議論をするた めに, ノード数 $|V|$ を 2 以上とする. 本研究では, 次数が 3 以上の ノードを結節点, 次数が 1 のノードを袋路の行き止まりと呼ぶこと もある。このグラフの隣接行列を $A$ で表す。すなわち, サイズが $|V| \times|V|$ の正方行列となり, その成分 $a_{i j}$ は

$$
a_{i j}= \begin{cases}1 & \text { ノード } i \text { と } j \text { とがリンクで結ばれる; } \\ 0 & \text { その他. }\end{cases}
$$

となり, 2 值を要素とする対称行列となる. 行列 $A$ の最大固有值を $\lambda$ ，それに属する固有ベクトルを $\mathrm{x}$ とすると，

$$
A \mathbf{x}=\lambda \mathbf{x}
$$

となる. 式 $(1)$ の成分表示は, $\delta(v)$ をノード $v$ と接続するノード 集合とすると,

$$
x_{v}=\frac{1}{\lambda} \sum_{u \in \delta(v)} x_{u}
$$

となる. Perron-Frobenius の定理より $\lambda>0$ 及び $\mathbf{x} \geq \mathbf{0}$ とな $3^{12) 13)}$. 式 (1) と式 (2) から, 次の 2 点が確認できる ${ }^{11)}$ :

(a-1) 固有ベクトル $\mathrm{x}$ は均衡条件を満たす。ノドの值が他のノー ドの值に影響し, さらにそれが自身のノードの值を変えてしまう複 雑な構造だが，それらの相互依存関係がすべて調整されている.

(a-2) 接続するノード数が多いほど, そして接続するノードでの值 が高いほど，そのノードの成分值も高くなる.

このような 2 つの性質から, 固有ベクトル $\mathrm{x}$ の成分值が高ければ, そのノードは利便性に優れると見なすことができるので，成分值は 地利値と呼ばれている(6)7)8). なお, 式 (1) と式 (2) からも分かる ように, $x_{i}$ は定数倍に関して自由度がある. 従って, あるノードの 地利值を固定した相対比較となる。

例えば, 図 3 に, 図 1 で切り出された直線部分（図中の $B$ ) での 地利值を示す. 2 つの拠点ノード $u$ 及び $w$ で地利值が極大で, 最大 である $w$ での地利値を 1.0 と基準化して相対表示する. 図から, そ れらの間のノードでは下に凸の形状となっていることが観察できる.

\section{2 グラフ上と最大固有值}

最大固有值の大きさは，グラフ上の地利值の分布形状に影響を与 える ${ }^{11)}$. グラフ構造と最大固有值との関係については, 以下の性質 が証明されている12)13)

(b-1) 最大固有值 $\lambda$ は, グラフの平均次数より大きく, 最大次数よ り小さい. つまり, ノード数 $|V|$, リンク数 $|E|$, 最大次数 $\rho_{\max }$ の グラフにおいて,

$$
\frac{2|E|}{|V|} \leq \lambda \leq \rho_{\max }
$$

となる。ただし，2つの等式はグラフが正則グラフのときにそれぞ れ成立する。

(b-2) 最大固有值 $\lambda$ は，グラフにリンクを追加すると大きくなる. 


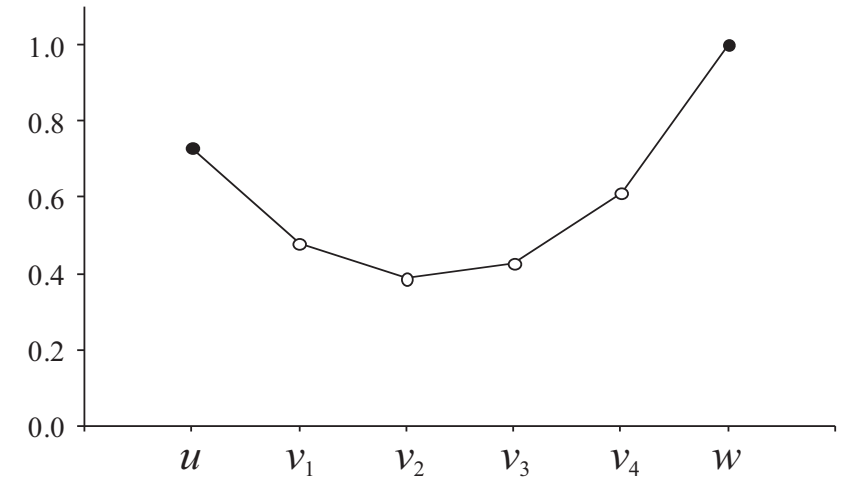

図 3 パス上の地利値

32 拠点パス・グラフ

\section{1 地利值}

本研究では, 地利值が外生的に与えられているノードを拠点ノ一 ドと呼ぶ. 図 4 に図説するように， 1 列に並んでいる $n-1$ 個のノー ドが 2 つの拠点ノードに挟まれている部分グラフを考える。なお， 図中の数字は地点を表す. 拠点ノードの地利值 $x_{0}$ や $x_{n}$ が他の地 利值 $x_{1}, x_{2}, \cdots, x_{n-1}$ にどのような影響を与えるのかを分析する.

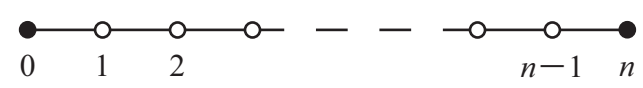

図 42 拠点パス・グラフ

式 (2) から, 2 拠点間の途中ノードにおいては次式が成り立つ：

$$
x_{i}=\frac{1}{\lambda}\left(x_{i-1}+x_{i+1}\right), \quad(i=1, \cdots, n-1) .
$$

ここで, 隣接行列の最大固有值が 2 以上, つまり,

$$
\lambda \geq 2
$$

を考える。

最大固有值 $\lambda$ が 2 未満となるグラフは, 図 5 に示すような 5 種類 に限定される ${ }^{12) 13)}$. 図 5 の 1 段目のような $q$ 個のノードが 1 列に 並ぶパス・グラフでは $\lambda=2 \cos \left(\frac{\pi}{q+1}\right)$ となる12)13)14)が， $\lambda>2$ となるグラフから部分グラフとして切り出すことで命題 1 を満たす. 図 5 の 2 段目のようにノードが 1 列でつながり，1つの端点が他の

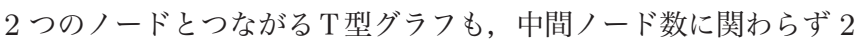

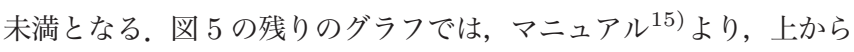
順に固有値は $\lambda \approx 1.9319, \lambda \approx 1.9696, \lambda \approx 1.9890$ となる.

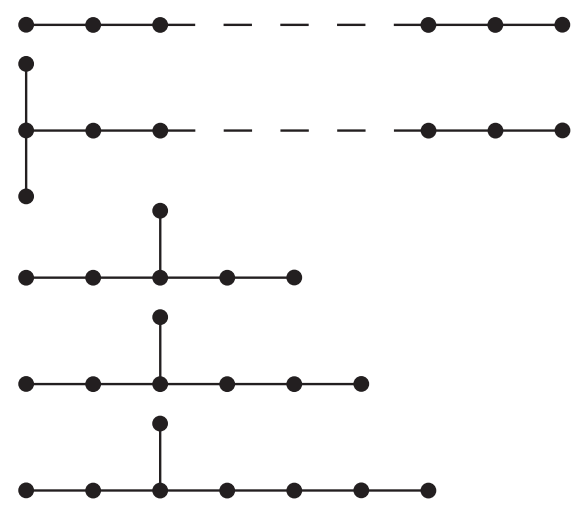

図 5 固有值が 2 未満のグラフ
ここで, パラメータ $\alpha$ を固有值 $\lambda$ の関数として次のように定義 する：

$$
\alpha \equiv \frac{\lambda+\sqrt{\lambda^{2}-4}}{2} .
$$

式 (4) と式 (5) から,

$$
\begin{aligned}
1 & <\alpha \\
\frac{1}{\alpha}=\frac{\lambda-\sqrt{\lambda^{2}-4}}{2} & <1 \\
\alpha+\frac{1}{\alpha} & =\lambda
\end{aligned}
$$

を得る。また，

$$
\begin{aligned}
& \lambda=2 \quad \Leftrightarrow \quad \alpha=1, \quad \lambda=\frac{5}{2} \Leftrightarrow \alpha=2, \\
& \lambda=4 \quad \Leftrightarrow \quad \alpha=2+\sqrt{3} .
\end{aligned}
$$

命題 1 端点の地利值 $x_{0}, x_{n}$ が与えられている. 地利值 $x_{i}$ は次の ようになる：

$$
\begin{gathered}
=\frac{1}{x_{i}}\left(\left(\alpha^{n-i}-\left(\frac{1}{\alpha}\right)^{n-i}\right) x_{0}+\left(\alpha^{i}-\left(\frac{1}{\alpha}\right)^{i}\right) x_{n}\right), \\
\quad(i=0, \cdots, n) .
\end{gathered}
$$

証明: 式 (9)の右辺に, $i=0$ 及び $i=n$ をそれぞれ代入すると, それぞれ $x_{0}$ と $x_{n}$ になることは明らかである.

次に, 式 (3) を証明する. 式 (8) から, 自然数 $s$ に対し,

$$
\begin{aligned}
& \alpha^{s-1}-\frac{1}{\alpha^{s-1}}+\alpha^{s+1}-\frac{1}{\alpha^{s+1}} \\
= & \left(\alpha^{s-1}+\alpha^{s+1}\right)-\left(\frac{1}{\alpha^{s-1}}+\frac{1}{\alpha^{s+1}}\right) \\
= & \alpha^{s}\left(\alpha+\frac{1}{\alpha}\right)-\frac{1}{\alpha^{s}}\left(\alpha+\frac{1}{\alpha}\right) \\
= & \lambda\left(\alpha^{s}-\frac{1}{\alpha^{s}}\right)
\end{aligned}
$$

が成り立つ。これを用いると，

$$
\begin{aligned}
\lambda\left(\alpha^{n-i}-\frac{1}{\alpha^{n-i}}\right) & =\left(\alpha^{n-i-1}-\frac{1}{\alpha^{n-i-1}}\right)+\left(\alpha^{n-i+1}-\frac{1}{\alpha^{n-i+1}}\right) \\
\lambda\left(\alpha^{i}-\frac{1}{\alpha^{i}}\right) & =\left(\alpha^{i-1}-\frac{1}{\alpha^{i-1}}\right)+\left(\alpha^{i+1}-\frac{1}{\alpha^{i+1}}\right)
\end{aligned}
$$

が得られる. 最初の式に $x_{0}$ を最後の式に $x_{n}$ をそれぞれ掛け，そ れらの和に係数 $\frac{1}{\alpha^{n}-\frac{1}{\alpha^{n}}}$ を両辺に掛けることにより, 左辺は $\lambda x_{i}$, 右辺は $x_{i+1}+x_{i-1}$ に一致する。こうして, 式 (3) を満たす。

なお，パスの中間点 $x_{\frac{n}{2}}$ を評価してみると,

$$
\lim _{n \rightarrow \infty} x_{\frac{n}{2}}=\left(x_{0}+x_{n}\right) \lim _{n \rightarrow \infty} \frac{\alpha^{\frac{n}{2}}-\frac{1}{\alpha^{\frac{n}{2}}}}{\alpha^{n}-\frac{1}{\alpha^{n}}}=0
$$

となり，直観に合う.

式 (9) が式 (3) を満たすと予想できるのは, 式 (3) が

$$
(\lambda-2) x_{i}=\left(x_{i-1}-x_{i}\right)+\left(x_{i+1}-x_{i}\right)
$$

と変形できる結果として, 定数係数の二階同次線形微分方程式で近 似的に表現できるからである， $\lambda>2$ という条件から, 正数 $q$, 係 数 $\omega$ 及び $\kappa$ を用いて, 微分方程式の解は

$$
\omega q^{-x}+\kappa q^{x}
$$

と表現できる ${ }^{22)}$. 


\section{2 指数型距離減衰とエコー効果}

命題 1 から, 次の 3 点が読み取れる. 第一に, 式 (6) 及び式 (7) から $\frac{1}{\alpha}<1<\alpha$ なので, 地利値 (9) における括弧内の第 1 項の $\alpha^{n-i}$ 及び $-\left(\frac{1}{\alpha}\right)^{n-i}$ は, 添え字 $i$ に関する減少関数である. 拠点 ノードの地利值 $x_{0}$ の影響が地点 0 から離れるに従って減少してい くことが分かる. 同様に, 第 2 項でも $x_{n}$ の影響が地点 $n$ から離れ るに従って減少していくことが分かる。このように, 地利值が距離 減衰となり, 地理学での基本的特性を表現できている.

第二に，相異なるノード間の距離をその間にあるリンク数とする と, 地利值 $(9)$ 括弧内の $\alpha^{n-i} や \alpha^{i}$ は, 純粋な指数関数型の距離 減衰関数となる. 実際, $\omega \equiv \alpha^{n}, \kappa \equiv \log \alpha$ と定義すると,

$$
\alpha^{n-i}=\omega \exp ^{-\kappa i}, \quad \alpha^{i}=\omega \exp ^{-\kappa(n-i)}
$$

となり, パラメータ $\alpha$ を距離抵抗とする典型的な指数関数の重力モ デルで表示できる，なお，性質 (b-2) から, 外部グラフでのリンク 新設は固有值 $\lambda$ を大きくする. 式 (5) から $\alpha$ は $\lambda$ の増加関数であ り, グラフの連結性の強化は距離抵抗 $\alpha$ を増加させるのである.

第三に, このような重力モデルとなる 2 つの項 $\alpha^{n-i}$ 及び $\alpha^{i}$ を 直接効果と呼ぶ。地利值は均衡状態から導かれるため, 自身の值が 相手を強化し, 結果として自身の影響力を弱めてしまう。拠点ノー ドからの影響は，相乗関係から端点に近いほど大きくなる。これ をエコー効果と呼ぶ．地利值 $(9)$ にて， $x_{0}$ に関するエコー効果は $\left(\frac{1}{\alpha}\right)^{n-i}, x_{n}$ に関するエコー効果は $\left(\frac{1}{\alpha}\right)^{i}$ となる。 これらは $\alpha^{i-n}$, $\alpha^{-i}$ と書き換えられるから, 端点に到達した直接効果が逆向きに転 じて反対側の外側から距離の指数関数で減衰していると解釈できる. エコー効果により, $\left(\frac{1}{\alpha}\right)^{n-i}$ だけ $x_{0}$ の影響が弱まっていることが 分かる. 同様に, 第 2 項でも $\left(\frac{1}{\alpha}\right)^{i}$ だけがエコー効果として $x_{n}$ の 効果が差し引かれている. 図 3 の地利值をエコー効果と直接効果に 分解して図 6 に示す.ノード $u$ の影響を。で, ノード $w$ の值を・ で表し, 直接効果とエコー効果をそれぞれ実線, 点線で結んでいる. 結節点における地理的優位性に関しては, 都市経済学の端点立 地 ${ }^{18)}$ やグラフでの八キミの定理 ${ }^{17) 23)}$ で指摘されている.これらの 理論での結節点は隣接するパス上のノードと比較して, 目的関数值 は優れるが, それぞれの関数值は 1 つのパス上にて結節点から距離 の線形であり, 指数関数のような滑らかな重力モデルの形状とはな らない.

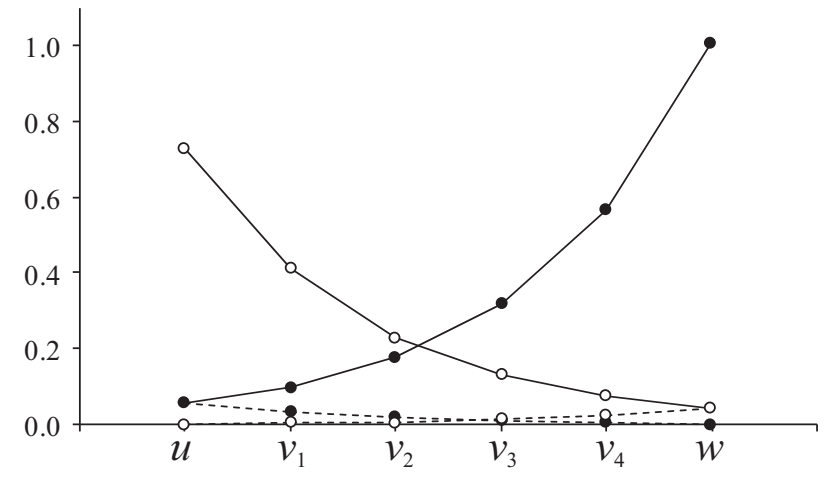

図 6 エコー効果と直接効果

\section{4 放射グラフ}

\section{1 地利値}

図 7 上段のように，部分グラフとして拠点ノードから放射状に パスが伸びる放射グラフ ${ }^{19)}$ を考える。 ただし，図 7 下段のように, 放射路ごとにリンク数が異なっていても構わない. $n+1$ 個のノー ドが 1 列に並んでいる 1 本の放射路を抽出し, 所与である拠点ノー ドの地利值 $x_{0}$ が地利值 $x_{1}, x_{2}, \cdots, x_{n}$ にどのように伝播するのか を観察する。
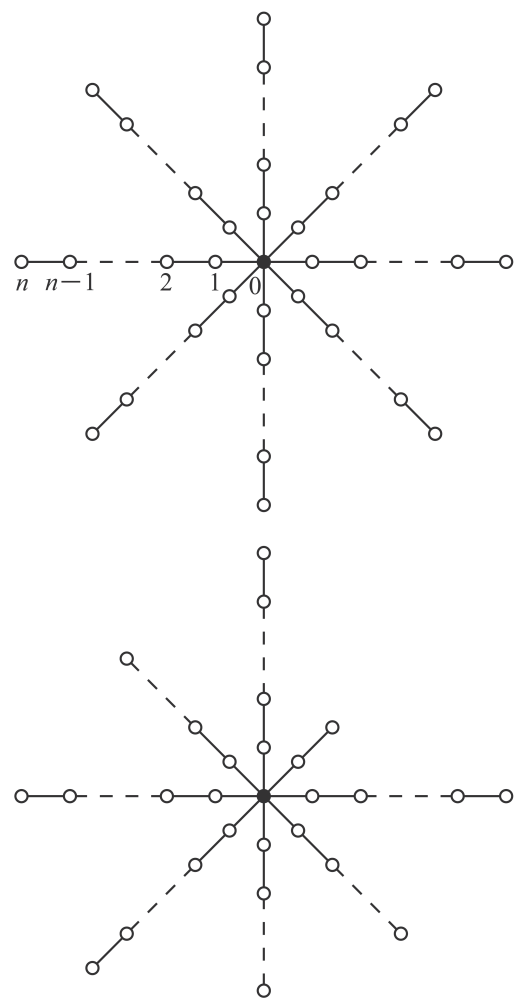

図 7 放射グラフ

図 7 では 8 本の放射路があるが, 対称性からリンク数が同じで ある放射路では地利值の分布は同一となる。そして, 端点までの途 中のノードは式 (3) を満たさなければならない. 加えて, 端点 $n$ に おいては式 $(2)$ から, 次式が成り立たなければならない：

$$
x_{n}=\frac{x_{n-1}}{\lambda} \text {. }
$$

放射グラフの地利值は, 前述の 2 拠点パス・グラフでの地利值 $(9)$ から直接計算できる.

命題 2 放射グラフの地利值 $x_{i}$ は次のようになる：

$$
\begin{array}{r}
x_{i}=\frac{\alpha^{n+2}}{\alpha^{2 n+2}-1}\left(\alpha^{n-i}-\frac{1}{\alpha^{2}}\left(\frac{1}{\alpha}\right)^{n-i}\right) x_{0}, \\
(i=0, \cdots, n) .
\end{array}
$$

証明：2つの拠点ノードに挟まれた $n$ 個のノードを考える. 従つて, ノード総数は $n+2$ となる. 外生的に, $n+1$ に位置する拠点ノー ドの地利値を $x_{n+1}=0$ とする. すると, 式 (10) は式 (3) において

$$
x_{n}=\frac{1}{\lambda}\left(x_{n-1}+x_{n+1}\right)
$$

として自動的に表現される. 従って, 地利值 (9)において, $n$ を $n+1$ に置き換え $x_{n+1}=0$ とし, 地利值 (11) が得られる. 
命題 2 は放射路の本数と無関係に成り立つことに留意して欲しい. 命題 1 と異なり外生変数は $x_{0}$ だけである. 地利值は定数倍に関 して自由度があり, 部分グラフ内では外部グラフのノードと接続す る拠点ノードとの相対比較で十分であるから， $x_{0}$ を基準に $\frac{x_{i}}{x_{0}}$ で評 価する. 相対比であるので, $\frac{x_{i}}{x_{0}}$ は拠点ノードとの格差をも表す.

端点 $x_{n}$ を評価してみると,

$$
\lim _{n \rightarrow \infty} \frac{x_{n}}{x_{0}}=\lim _{n \rightarrow \infty} \frac{\alpha-\frac{1}{\alpha}}{\alpha^{n+1}-\frac{1}{\alpha^{n+1}}}=0 .
$$

なお， $x_{0}$ も内生化された場合の地利值は，図 5 のパス・グラフな ので, 固有值 $\lambda$ は, $\lambda<2$ であり, $\lambda>2$ の条件の下で導かれた地 利值 $(11)$ は, この結果を含むことはできない.

\section{2 波及効果と無記憶性}

命題 2 から次の 3 点が読み取れる. 第一に, 地利值が拠点ノー ドからの指数型距離減衰関数になることを確認した.

第二に, 外部グラフでのリンク新設は部分グラフ内の地利值の差 異を大きくする。このような外部の影響を証明する．性質 (b-2) か ら, 地利值 $\frac{x_{i}}{x_{0}}$ が固有值 $\lambda$ の減少関数であることを示せばよい. そ こで, $\frac{x_{i}}{x_{0}}$ が $\alpha$ の減少関数であることを証明する. $\kappa \equiv 2 n+2$ と すると, 式 (11) から, $\frac{x_{i}}{x_{0}}$ を $\alpha$ の関数として次のように表現する：

$$
h_{i}(\alpha) \equiv \frac{x_{i}}{x_{0}}=\frac{\alpha^{\kappa-i}-\alpha^{i}}{\alpha^{\kappa}-1} .
$$

$h_{i}(\alpha)$ を $\alpha$ で微分すると, 導関数 $h_{i}^{\prime}(\alpha)$ は

$$
\begin{aligned}
& h_{i}^{\prime}(\alpha)\left(\alpha^{\kappa}-1\right)^{2} \\
= & \left((\kappa-i) \alpha^{\kappa-i-1}-i \alpha^{i-1}\right)\left(\alpha^{\kappa}-1\right)-\kappa \alpha^{\kappa-1}\left(\alpha^{\kappa-i}-\alpha^{i}\right) \\
= & (\kappa-i) \alpha^{2 \kappa-i-1}-i \alpha^{\kappa+i-1}-(\kappa-i) \alpha^{\kappa-i-1}+i \alpha^{i-1} \\
& \quad-\kappa \alpha^{2 \kappa-i-1}+\kappa \alpha^{\kappa+i-1} \\
= & -i \alpha^{2 \kappa-i-1}+(\kappa-i) \alpha^{\kappa+i-1}-(\kappa-i) \alpha^{\kappa-i-1}+i \alpha^{i-1} \\
= & -i(\kappa-i) \alpha^{\kappa-1}\left(\frac{\alpha^{\kappa-i}-\alpha^{i-\kappa}}{\kappa-i}-\frac{\alpha^{i}-\alpha^{-i}}{i}\right) .
\end{aligned}
$$

ここで, $\kappa-i>i$ に注意すれば,

$$
\frac{\alpha^{\kappa-i}-\alpha^{i-\kappa}}{\kappa-i}>\frac{\alpha^{i}-\alpha^{-i}}{i}
$$

となる。なぜならば,

$$
\begin{aligned}
& \frac{\alpha^{i}-\alpha^{-i}}{i} \\
= & \left(\frac{\alpha-\alpha^{-1}}{i}\right)\left(\alpha^{i-1}+\alpha^{i-3}+\cdots+\alpha^{-i+3}+\alpha^{-i+1}\right) \\
= & \left(\frac{\alpha-\alpha^{-1}}{i}\right) \alpha^{i-1}\left(\frac{1-\left(\alpha^{-2}\right)^{i-1}}{1-\alpha^{-2}}\right) \\
= & \left(\frac{\alpha-\alpha^{-1}}{i}\right)\left(\frac{\alpha^{2}}{\alpha^{2}-1}\right)\left(\alpha^{i-1}-\alpha^{1-i}\right) \\
= & \left(\alpha-\alpha^{-1}\right) \frac{\left(\frac{\alpha^{2}}{\alpha^{2}-1}\right)^{i}}{i}
\end{aligned}
$$

となり, $i$ に関して単調増加関数である.こうして, 導関数 $h_{i}^{\prime}(\alpha)$ の符号は, $h_{i}^{\prime}(\alpha)<0$ となる. 外部グラフでのリンク新設という 連結性強化は, 拠点ノードを通して部分グラフ内へ影響するが, 拠
点ノードからの伝播の強さは末端に広がるに従って弱くなり, 拠点 ノードとそれ以外のノードとの地利值格差を拡大すると解釈できる.

最後に, $n$ が大きい時, 地利值 (11) は次のように表現できる.

$$
\frac{x_{i}}{x_{0}}=\left(\frac{1}{\alpha}\right)^{i}, \quad(i=0, \cdots) .
$$

従つて, ノード $j$ に対し, 十分に小さい $i(\geq j)$ について,

$$
\frac{x_{i}}{x_{j}}=\left(\frac{1}{\alpha}\right)^{i}\left(\frac{1}{\alpha}\right)^{-j}=\left(\frac{1}{\alpha}\right)^{i-j}
$$

が成立する.これから, 拠点をノード 0 からノード $j$ へ変更したと しても表現が変わらない, つまり拠点変更に関して不変となる無記 憶性 ${ }^{24)}$ が成り立つ。

\section{5 放射環状グラフ}

\section{1 放射環状グラフ}

部分グラフとして図 8 のように, 放射路に並ぶ $n$ 個のノードが $n$ 本の環状路で結合する放射環状グラフ ${ }^{19)}$ を考える. 拠点ノードを 起点とする放射グラフと $n$ 本の環状グラフとの結合である.

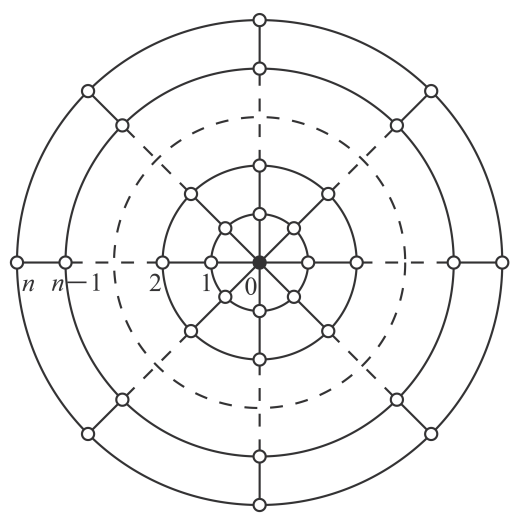

図 8 放射環状グラフ

ここでは, $\lambda>4$ を仮定する. 性質 (b-1) から, 最大固有值 $\lambda$ の 下限值は平均次数で与えられる. 図 8 での平均次数はおおよそ 4 で あるから，この仮定は妥当である.

$$
\begin{aligned}
\text { このグラフでは } \\
x_{n}=\frac{2 x_{n}+x_{n-1}}{\lambda}, \\
x_{i}=\frac{1}{\lambda}\left(x_{i-1}+2 x_{i}+x_{i+1}\right), \quad(i=1, \cdots, n-1)
\end{aligned}
$$

を満たさなければならない.式 (13) は

$$
x_{i}=\frac{1}{\lambda-2}\left(x_{i-1}+x_{i+1}\right)
$$

と変形できる.これと式 (3), 式 (12) と式 (10) との違いはそれぞ れ $\lambda$ と $\lambda-2$ だけである。 そこで, パラメー夕 $\beta$ を次のように定 義する：

$$
\beta \equiv \frac{\lambda-2+\sqrt{(\lambda-2)^{2}-4}}{2} .
$$

命題 3 放射環状グラフの地利值 $x_{i}$ は次のようになる :

$$
\begin{array}{r}
x_{i}=\frac{\beta^{n+2}}{\beta^{2 n+2}-1}\left(\beta^{n-i}-\frac{1}{\beta^{2}}\left(\frac{1}{\beta}\right)^{n-i}\right) x_{0}, \\
(i=0, \cdots, n) .
\end{array}
$$

証明：式 (11) にて $\alpha$ に $\beta$ を代入すれば，(15) となる. 


\section{2 部分放射環状グラフ}

図 9 上段のような拠点ノードからの 2 本の放射路を環状路で結 ぶ扇形のグラフを考える。放射環状グラフの部分集合であるので, 部分放射環状グラフと呼ぶ．ただし，各扇型で放射路リンク数が異 なってもよい. また，図 9 下段のように 1 本の放射路からの環状路 が異なる放射路を結んでもよい. $n$ 個のノードが $n$ 本の環状路で結 合する 1 つの扇形を抽出し, 部分グラフでの地利值を分析する.

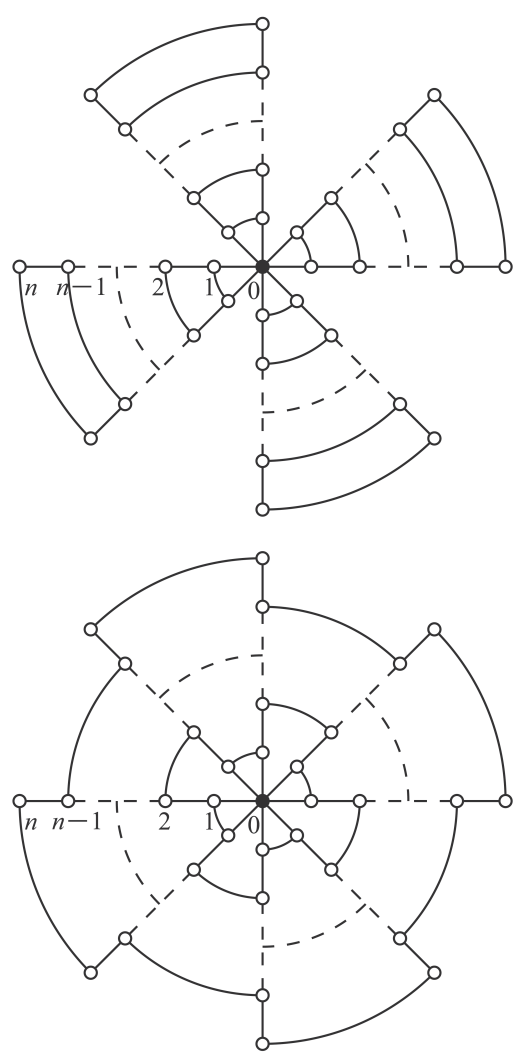

図 9 部分放射環状グラフ

ここでは， $\lambda>3$ と仮定する. 図 9 での平均次数はおよそ 3 で あり, この仮定は妥当である.このグラフでは,

$$
\begin{aligned}
x_{n} & =\frac{x_{n}+x_{n-1}}{\lambda}, \\
x_{i} & =\frac{1}{\lambda}\left(x_{i-1}+x_{i}+x_{i+1}\right), \quad(i=1, \cdots, n-1)
\end{aligned}
$$

を満たさなければならない. 最後の式は,

$$
x_{i}=\frac{1}{\lambda-1}\left(x_{i-1}+x_{i+1}\right)
$$

と等価である.なお, 図 9 の 2 つのグラフは, 式 (16) 及び式 (17) を満たすから，両者の地利値分布は同一となる.

上式と式 (3), 式 (16) と式 (10) の違いはそれぞれ $\lambda$ と $\lambda-1$ だ けである. よって, パラメー夕 $\gamma$ を次のように定義する：

$$
\gamma \equiv \frac{\lambda-1+\sqrt{(\lambda-1)^{2}-4}}{2} .
$$

命題 4 部分放射環状グラフの地利值 $x_{i}$ は次のようになる :

$$
\begin{array}{r}
x_{i}=\frac{\gamma^{n+2}}{\gamma^{2 n+2}-1}\left(\gamma^{n-i}-\frac{1}{\gamma^{2}}\left(\frac{1}{\gamma}\right)^{n-i}\right) x_{0}, \\
(i=0, \cdots, n) .
\end{array}
$$

証明：式 (11) にて， $\alpha$ の代わりに $\gamma$ を代入する.

\section{3 環状路の意義}

地利值を用いて環状路の整備効果 ${ }^{25)}$ を把握する. $n=5$ の完全 型及び部分型の放射環状グラフと図 7 上段の放射グラフについて地 利值 $\frac{x_{i}}{x_{0}}$ を図 10 の一点鎖線, 点線及び実線でそれぞれ示す. 横軸 が添え字 $i$, つまり, 拠点ノード 0 からの距離を表し, 縦軸が地利 值 $\frac{x_{i}}{x_{0}}$ である. ただし, $\lambda=5.0$ であり, この值は, 図 1 に例示し たように, 拠点ノードだけを経由して接続する外部グラフのグラフ 構造を調整することにより得られる。

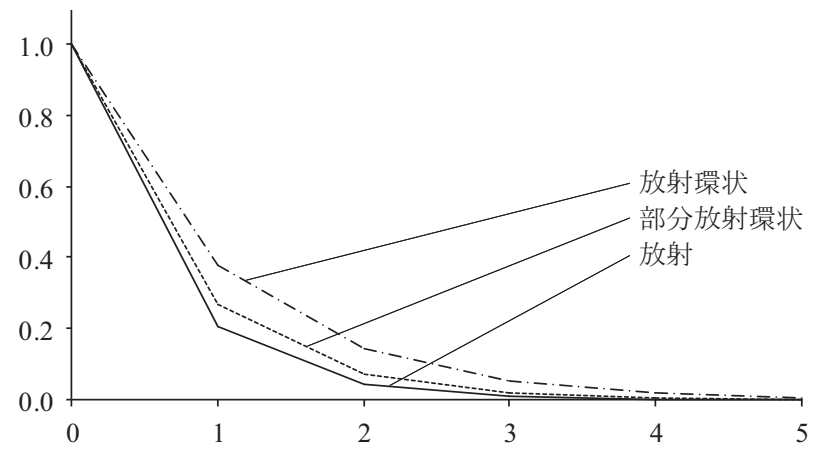

図 10 環状路の影響 $(\lambda=5.0)$

図より, 拠点ノードから離れるに従い地利值が逓減することが観 察できる. 3 本の関数は, 一点鎖線, 点線, 実線の順で小さくなっ ており, 放射環状, 部分放射環状, 放射の順で地利值が低下するこ とが分かる，このように均質なノードの集合ではあるが，同心円構 造における地利值が重力モデルとして説明できることが確認できた.

実際, 式 (5), 式 (18), 式 (14) から, 距離抵抗パラメー夕の大 小関係として, $\alpha>\gamma>\beta$ となる. 従って, 命題 2 , 命題 3 , 命題 4 より, 地利值 (11), 地利值 (19), 地利値 (15) の順に高くなる. このように, 環状路の建設は $\frac{x_{i}}{x_{0}}$ を上昇させることが分かる. 環状 路が増えるにつれて地利值の差異が小さくなり拠点ノードの求心力 は弱まる. 故に, 環状路リンクの増加は地利值の格差を是正するの である。

\section{6 外環状グラフ}

\section{1 外環状グラフ}

図 11 のように, 外側の $n$ 個のノードを 1 本の環状路で結ぶ部分 グラフを考える．拠点ノードを起点とする放射グラフと 1 本の外環 状路との結合である。これを外環状グラフと呼ぶ.

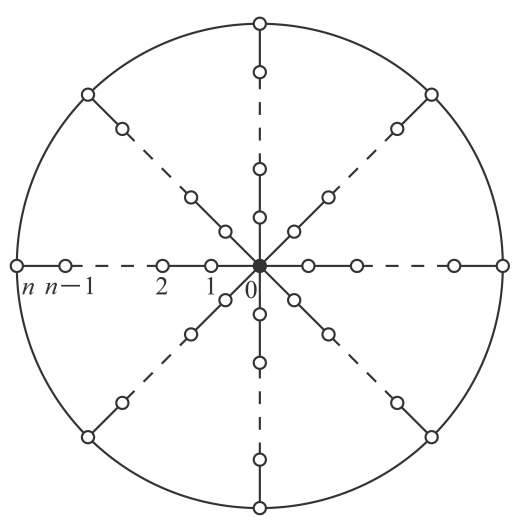

図 11 外環状グラフ 
外環状路までの途中のノードでは, 式 (3) を満たす必要がある. また，外環状路との結節点では式 (12) を満たさなければならない. 命題 1 と同様な証明により次の命題を得る：

命題 $\mathbf{5}$ 外環状グラフの地利値 $x_{i}$ は次のようになる：

$$
\begin{gathered}
=\frac{x_{i}^{n}}{\alpha^{2 n}+\left(\frac{2 \alpha-1}{\alpha(\alpha-2)}\right)}\left(\alpha^{n-i}+\left(\frac{2 \alpha-1}{\alpha(\alpha-2)}\right)\left(\frac{1}{\alpha}\right)^{n-i}\right) x_{0}, \\
\quad(i=0, \cdots, n) .
\end{gathered}
$$

証明: 式 (20) の右辺に $i=0$ を代入すれば $x_{0}$ となることは容 易に確かめられる.

次に, 式 (3) を満たすことを証明する. 単純化のために, 式 (20) の係数部分 $\kappa \equiv \frac{x_{0}}{(\alpha-2) \alpha^{n}+(2 \alpha-1) \alpha^{-n-1}}$ と定義する. 式 (8) を用 いて,

$$
\begin{aligned}
& \frac{1}{\kappa}\left(x_{i+1}+x_{i-1}\right) \\
= & \left((\alpha-2) \alpha^{n-i-1}+(2 \alpha-1) \alpha^{i-n}\right) \\
& \quad+\left((\alpha-2) \alpha^{n-i+1}+(2 \alpha-1) \alpha^{i-n-2}\right) \\
= & (\alpha-2) \alpha^{n-i}\left(\alpha+\frac{1}{\alpha}\right)+(2 \alpha-1) \alpha^{i-n-1}\left(\alpha+\frac{1}{\alpha}\right) \\
= & \left(\alpha+\frac{1}{\alpha}\right) \frac{x_{i}}{\kappa}=\lambda \frac{x_{i}}{\kappa} .
\end{aligned}
$$

最後に，式 (12) を満たすことを確認する.

$$
\begin{aligned}
(\lambda-2) x_{n} & =\kappa(\lambda-2)\left((\alpha-2)+(2 \alpha-1) \frac{1}{\alpha}\right) \\
& =\kappa\left(\alpha+\frac{1}{\alpha}-2\right)\left(\alpha-\frac{1}{\alpha}\right) \\
& =\kappa\left((\alpha-2) \alpha+(2 \alpha-1) \frac{1}{\alpha^{2}}\right)=x_{n-1}
\end{aligned}
$$

となり, 式 (12) も成り立つ.

地利值 (20) には, エコー効果は取り込まれているが, 式中の表 現では, 拠点ノードから放射路で伝わる内側の効果 $\alpha^{n-i}$ と外環状 路方向から伝わる外側の効果 $\alpha^{i}$ との合計となっている.

\section{2 部分外環状グラフ}

部分グラフとして図 12 のように, 拠点から伸びる扇形の集合を 考える．各扇形では，拠点ノードから 2 本の放射路が外環状路と接 続している。これを部分外環状グラフと呼ぶ。ただし, 各扇形の放 射路のリンク数は異なっても構わない.

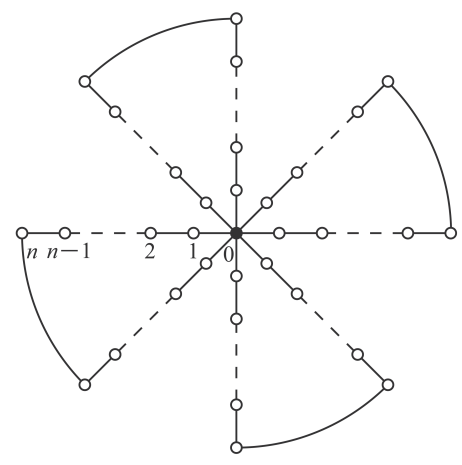

図 12 部分外環状グラフ
外環状路までの途中のノードは式 (3) を満たさなければならない. 加えて, 最終端点 $n$ においては次式が成り立たなければならない:

$$
x_{n}=\frac{x_{n-1}+x_{n-1}}{\lambda} .
$$

しかし，部分外環状グラフは $2 n+1$ 個のノードが巡回するグラ フとも見なせるので，その地利值は， 2 拠点ノードでの地利值 $(9)$ から直接計算できる. 命題 1 において, $n$ を $2 n$ に, $x_{n}$ を $x_{0}$ に置 き換えて, 部分外環状グラフの地利值が得られる。

命題 6 部分外環状グラフの地利值 $x_{i}$ は次のようになる :

$x_{i}=\frac{\alpha^{n}}{\alpha^{2 n}+1}\left(\alpha^{n-i}+\left(\frac{1}{\alpha}\right)^{n-i}\right) x_{0}, \quad(i=0, \cdots, n)$.

証明：式 (9) にて, $x_{n}=x_{0}$ とし $n$ に $2 n$ を代入し,

$$
\begin{aligned}
\frac{x_{i}}{x_{0}} & =\frac{1}{\alpha^{2 n}-\frac{1}{\alpha^{2 n}}}\left(\alpha^{2 n-i}-\frac{1}{\alpha^{2 n-i}}+\alpha^{i}-\frac{1}{\alpha^{i}}\right) \\
& =\frac{1}{\alpha^{2 n}-\frac{1}{\alpha^{2 n}}}\left(\alpha^{2 n-i}\left(1-\frac{1}{\alpha^{2 n}}\right)+\alpha^{i}\left(1-\frac{1}{\alpha^{2 n}}\right)\right) \\
& =\frac{1}{\alpha^{4 n}-1}\left(\alpha^{i}+\alpha^{2 n-i}\right)\left(\alpha^{2 n}-1\right) \\
& =\frac{\alpha^{i}+\alpha^{2 n-i}}{\alpha^{2 n}+1} .
\end{aligned}
$$

式 (21) は, 式 (9) から導出されているので, エコー効果は取り 込まれているが, 式中の表現では, 拠点ノードから伝わる内側の効 果 $\alpha^{n-i}$ と外環状路方向から伝わる外側の効果 $\alpha^{i}$ との合計となっ ている.

\section{3 外環状路の意義}

完全型及び部分型の外環状グラフと放射グラフに対して地利值を 計算する. $n=5$ の地利值 $\frac{x_{i}}{x_{0}}$ を, 図 13 の破線, 点線及び実線に てそれぞれ結ぶ. 図 10 同様に横軸が添え字 $i$, 縦軸が地利值 $\frac{x_{i}}{x_{0}}$ で ある.ただし， $\lambda=2.6$ である。

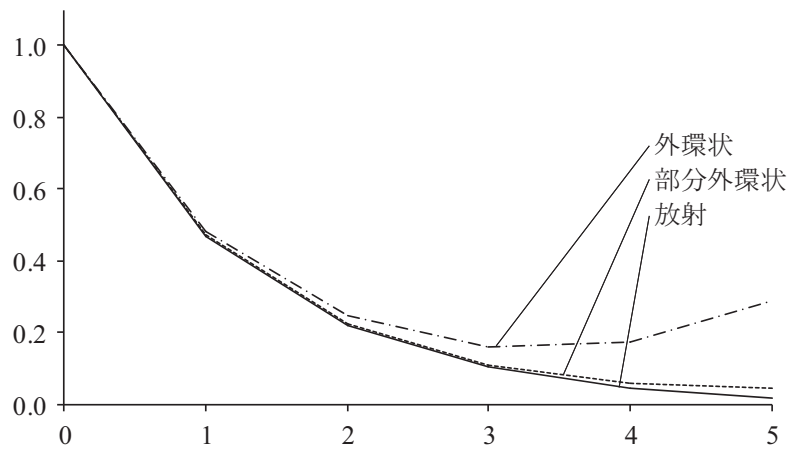

図 13 外環状路の影響 $(\lambda=2.6)$

この図の 3 本のグラフにて一点鎖線，点線，実線と下がってお り, 外環状, 部分外環状, 放射の順で地利值が低下することが分か る。また，放射グラフに着目して図 13 と図 10 とを比較すると，同 じ場所でも固有值の大きい結果である図 10 の地利值が低く, 拠点 との格差が大きいことが見てとれる。このように，グラフ全体での 連結性が高まるとノード間での地利值格差が拡大することが, 数值 的にも確認できた. 
図 13 , 命題 5 及び命題 6 から次の 4 点が読み取れる。第一に, 部分外環状グラフでは, 拠点ノードから離れるにつれて地利值 $(21)$ は派減する。しかし, 外環状グラフでは外環状路に近づくにつれて 地利值が増加する様子が観察できる。外環状結節点がサブ拠点の機 能を担っていると言える。これは，他の同心円構造では見られない， 外環状グラフ特有の性質である. 拠点ノードから放射路に沿って並 ぶ次数 2 から, サブ拠点の次数が 3 と増加に転じるからであろう. しかし, 部分型では外環状路の効果があまり発揮できていない.

第二に, 外環状路が地利值格差をどの程度変化させるか計算する. 実際, 正数 $\theta>0$ に対し, 外環状グラフ及び部分外環状グラフの地 利值 $\frac{x_{i}}{x_{0}}$ をともに含む一般形として,

$$
f_{i}(\alpha) \equiv \frac{\alpha^{\kappa-i}+\theta \alpha^{i}}{\alpha^{\kappa}+\theta}
$$

と定義する. ただし， $\kappa \equiv 2 n$ とすると，一般形での地利值 $(22)$ を $x_{i}$, 放射グラフでの地利值を $y_{i}$ とすると,

$$
\begin{aligned}
& f_{i}(\alpha)-\frac{y_{i}}{y_{0}} \\
= & \frac{\alpha^{\kappa-i}+\theta \alpha^{i}}{\alpha^{\kappa}+\theta}-\frac{\alpha^{\kappa+2-i}-\alpha^{i}}{\alpha^{\kappa+2}-1} \\
= & \frac{\left(\theta \alpha^{i}+\alpha^{\kappa-i}\right)\left(\alpha^{\kappa+2}-1\right)-\left(\alpha^{\kappa+2-i}-\alpha^{i}\right)\left(\alpha^{\kappa}+\theta\right)}{\left(\alpha^{\kappa}+\theta\right)\left(\alpha^{\kappa+2}-1\right)} \\
= & \frac{\alpha^{i}\left(\theta \alpha^{\kappa+2}+\alpha^{\kappa}\right)-\alpha^{\kappa-i}\left(1+\theta \alpha^{2}\right)}{\left(\alpha^{\kappa}+\theta\right)\left(\alpha^{\kappa+2}-1\right)} \\
= & \frac{\left(\theta \alpha^{2}+1\right)\left(\alpha^{\kappa+i}-\alpha^{\kappa-i}\right)}{\left(\alpha^{\kappa}+\theta\right)\left(\alpha^{\kappa+2}-1\right)} \\
= & \frac{\alpha^{\kappa}\left(\theta \alpha^{2}+1\right)\left(\alpha^{i}-\alpha^{-i}\right)}{\left(\alpha^{\kappa}+\theta\right)\left(\alpha^{\kappa+2}-1\right)} \geq 0 .
\end{aligned}
$$

このように, 外環状路の建設は地利值格差を縮小させることが分か る. 拠点ノードから離れるに従い, 縮小幅が指数関数的に増加する, つまり端部にて加速度的に改善する。

第三に, 固有値（距離抵抗）の大きさを

$$
\lambda>\frac{5}{2} \quad(\Leftrightarrow \alpha>2)
$$

と限定した場合を考える。これは，図 11 からも分かるように，平 均次数から見て妥当である。すると, 外環状グラフの地利值 $(20)$ でも外環状路方向からの影響が正となる.

第四に, 外環状グラフ, 部分外環状グラフともに外部グラフでの リンク新設は部分グラフ内の地利值格差を大きくする。これを， $\frac{x_{i}}{x_{0}}$ が $\lambda$ の減少関数となることで示す. 地利值 $(22)$ の導関数 $f_{i}^{\prime}(\alpha)$ は

$$
\begin{aligned}
& f_{i}^{\prime}(\alpha)\left(\alpha^{\kappa}+\theta\right)^{2} \\
= & \left(i \theta \alpha^{i-1}+(\kappa-i) \alpha^{\kappa-i-1}\right)\left(\alpha^{\kappa}+\theta\right)-\left(\theta \alpha^{i}+\alpha^{\kappa-i}\right)\left(\kappa \alpha^{\kappa-1}\right) \\
= & i \theta^{2} \alpha^{i-1}+\theta(\kappa-i) \alpha^{\kappa-i-1}+\theta(i-\kappa) \alpha^{\kappa+i-1}-i \alpha^{4 n-i-1} \\
= & \alpha^{\kappa-1}\left(\theta(i-\kappa)\left(\alpha^{i}-\alpha^{-i}\right)-i\left(\alpha^{\kappa-i}-\theta^{2} \alpha^{i-\kappa}\right)\right) .
\end{aligned}
$$

部分外環状グラフでは $\theta=1$ であり, 括弧内の 2 つの項ともに負とな るので, $f_{i}^{\prime}(\alpha)<0$ となる. 外環状グラフでは $\theta=\frac{2 \alpha-1}{\alpha(\alpha-2)}$ となる. 第 1 項は負であり, ここでも, 条件 $(23)$ が成立すれば, 第 2 項も負 となり, 外環状グラフでも $f_{i}^{\prime}(\alpha)<0$ となる. $\alpha^{\kappa-i}>\theta^{2} \alpha^{i-\kappa} \Leftrightarrow$ $\alpha^{\kappa-i}>\theta$ であるから, $\alpha>\theta$ を示せば第 2 項も負となる. 実際に $\alpha^{2}(\alpha-2)-(2 \alpha-1)=\alpha^{3}-2 \alpha^{2}-2 \alpha+1=(\alpha+1)\left(\alpha^{2}-\alpha-1\right)>0$ である.

\section{7 おわりに}

本研究では, 人口や商業などの規模, ノード間実距離などの要素 を排除した単純な構造を表現するグラフにおいて, 隣接関係という 地理的条件の違いのみで発生する地利值を分析の対象とした。

本研究では, 少なくとも以下の 5 点の知見を導いた。第一に, 地 利値には, 重力モデルという指数関数型の距離減衰構造が働く. 第 二に, 均衡条件から導かれる地利值には，他のノードに与えた影響 が自身に戻るというエコー効果が存在する。第三に, 対象地域での 環状路の建設は, 拠点ノードの求心性を弱め地利值格差是正に貢献 する. 第四に, 環状路として外環状路だけの建設は, 拠点ノード以 外にサブ拠点を創出させる. 最後に, 外部グラフでのリンク新設と いう全体の連結性強化は, 結果として部分グラフ内の地利值格差を 助長させる.これらの知見はいずれも直観に合う妥当なものである. 謝辞

本研究は, 科学研究費補助金 (基盤 B : 18330057) の成果である. 筑波大学岡本直久先生, 八森正泰先生, 小林隆史先生そして匿名の 査読者からコメントを頂戴した。記して感謝申し上げます。

参考文献

1）池澤寛：市民のための都市再生一商店街活性化を科学する一，学芸出版社， 2002

2) 青木義次 : 建築計画・都市計画の数学一規模と安全の数理 - , 数理工学社, 2006

3) Wilson, A.G.: Entropy in Urban and Regional Modelling, Pion Limited, London, 1970

4) 石川義孝: 空間的相互作用モデルーその系譜と体系一, 地人書房, 1988

5) Clark, C.: Urban Population Density, Journal of Royal statsitical Society, A, 114(12), pp.490-496, 1951

6) 野田洋 : 街路網の形態的特性に基づく定量的地利値の導入とその基礎的考察, 日本建築学会計画系論文集，470，pp.139-148，1995.4

7) 野田洋 : 街路網が生成する「地の利」に関する定量的尺度の応用的研究，都 市計画論文集，31，pp.55-60，1996

8) 野田洋 : 定量的地利尺度を用いた都市街路網の分析的研究, 日本建築学会計 画系論文集，519，pp.171-178，1999.5

9) 鵜飼孝盛, 栗田治 : 交通網により生成される都市平面上の地利值分布, 都市 計画論文集，38-3，pp.163-168，2003

10）鵜飼孝盛, 栗田治：地域間の相互作用に依存した都市活動分布の理論と連続 平面への一般化，都市計画論文集，40-3，pp.103-108，2005

11) 大澤義明, 林利充: 隣接グラフと地利值最大化, 日本建築学会計画系論文集, 633, pp.2417-2424, 2008.11

12) Schwenk, A.J. and R.J. Wilson: On the eigenvalues of a graph, (eds. L.W. Beineke and R.J. Wilson) Selected Topics in Graph Theory, Academic Press, London, pp.307-336, 1978

13) Doob, M. : Eigenvalues of graphs, (eds. L.W. Beineke and R.J. Wilson) Topics in Graph Theory, Cambridge University Press, New York, pp.30-55, 2005

14）竹中淑子 : 線形代数的グラフ理論, 培風館, 1989

15) Read, R.C. and R.J. Wilson : An Atlas of Graphs, Oxford Science Publications, Oxford, 1998

16) Griffith, D.A.: Spatial Autocorrelation and Spatial Filtering, Springer, Berlin, 2003

17) 奥平耕造 : 都市工学読本, 彰国社, 1976

18) 宮尾尊弘：現代都市経済学, 日本評論社, 1985

19) Vaughan, R.: Urban Spatial Traffic Patterns, Pion Limited, London, 1987

20) Mosler, K.C.: Continuous Location of Transportation Networks, Springer-Verlag, Berlin, 1987

21）秋山政敬：図説都市構造, 鹿島出版会, 1990

22）古屋茂: 微分方程式入門, サイエンス社, 1970

23) 伊理正夫, 古林隆 : ネットワーク理論, 日科技連, 1976

24) 牧本直樹 : 待ち行列アルゴリズム, 朝倉書店, 2001

25）日経コンストラクション：環状道路の時代, 日経 BP 社, 2006 